\title{
Array Comparative Genomic hybridization of breast cancer in the kingdom of Saudi Arabia
}

\author{
Lina Al-Harbi ${ }^{1}$, Ahmed Shokry ${ }^{2,3}$, Jamal Sabir ${ }^{2}$, Adeel Chaudhary ${ }^{1}$, Ashraf Dallol ${ }^{1 *}$ \\ From 2nd International Genomic Medical Conference (IGMC 2013) \\ Jeddah, Kingdom of Saudi Arabia. 24-27 November 2013
}

\begin{abstract}
Background
Breast cancer is the second most common cause of cancer death worldwide and is the most common cancer among Saudi females [1]. Breast carcinogenesis is associated by a wide-array of cytogenomic changes involving deletions, amplification or translocations of part or whole chromosome arms. However, there are several changes that could not be detected at the resolution offered by classical cytogenetic techniques. Many of these regions could provide further insight into the disease and may harbor potential prognostic values. The development of Array Comparative Genomic Hybridization $(\mathrm{aCGH})$ allowed the identification of such regions at a genomic scale and currently there is a plethora of scientific publications reporting cytogenomic changes in different cancer types [2]. Unfortunately, there are no studies as yet published specifically looking at breast cancer from Saudi patients.
\end{abstract}

\section{Materials and methods}

In this study, aCGH was performed on twenty breast cancer tumors and their matching non-tumorous (normal) tissues using the Agilent $2 \times 400 \mathrm{~K}$. Several regions were identified to be either amplified or deleted in a tumor-specific manner.

\section{Results}

All samples were obtained from female cancer patients diagnosed with breast cancer and were subjected to breast lumpectomy surgical procedure. The mean age of this group is 51.5 years, range: $35.0-70.1$ years. 15 cases were diagnosed with invasive ductal carcinoma (IDC), 2 cases were diagnosed with invasive lobular carcinoma and 2

\footnotetext{
* Correspondence: adallol@kau.edu.sa

${ }^{1}$ Center of Excellence in Genomic Medicine Research, King Abdulaziz

University, Jeddah 21589, Saudi Arabia

Full list of author information is available at the end of the article
}

cases were fibroadenomas. One case was of mucinous carcinoma origin. The main inclusion criteria were the presence of matching non-malignant normal tissue DNA from the same patient to be used as a reference DNA for the aCGH. This is important as it is often difficult to obtain good normal control DNA for breast cancer. The most prevalent chromosome imbalances were chromosome gains of $+1 \mathrm{q},+8 \mathrm{q},+11 \mathrm{q},+16 \mathrm{q}$ and $+20 \mathrm{q}$. Chromosome loss was mostly found in 11p, 13q, 1p, 9q, 16p, 17q, and Xq. In this study, gains were found in 1q25.1, 16q13$24,20 \mathrm{q} 11-13$, and $8 \mathrm{q} 21-24$. Of the DNA copy number losses, 1 p36 was most common event, followed by $8 p, 16 q$ and $17 \mathrm{p}$.

\section{Conclusions}

This is the first report of high resolution comparative genomic hybridization (aCGH) analysis of breast cancer from Saudi Arabia. We demonstrate our ability to detect known regions of amplification and deletions that occur in a tumor-specific manner. This finding serves as a validation to our approach as we are able to compare our findings to published benchmarks. We further demonstrate the potential importance of aCGH in breast cancer diagnosis as, through the detection of copy number changes, a patient sample can be characterized in terms of the cytogenetic aberrations it harbors. The detection of 1q, 1p, 8q amplification events by aCGH and FISH suggests that a considerably larger study can be established where as a significantly larger cohort with clinicopathological data can be analyzed using only FISH analysis. Prognostic biomarkers can then be identified if correlations could be made with copy number variations in these regions and known clinicopathological parameters, especially recurrence and survival.

(c) 2014 Al-Harbi et al; licensee BioMed Central Ltd. This is an Open Access article distributed under the terms of the Creative Commons 


\section{Authors' details}

${ }^{1}$ Center of Excellence in Genomic Medicine Research, King Abdulaziz

University, Jeddah 21589, Saudi Arabia. ${ }^{2}$ Department of Biological Sciences, Faculty of Science, King Abdulaziz University, P.O. Box 80141 Jeddah 21589, Saudi Arabia. ${ }^{3}$ Agricultural Genetic Engineering Research Institute (AGERI),

Agriculture Research Center (ARC), Giza, Egypt.

Published: 2 April 2014

\section{References}

1. Al-ldrissi H: Pattern of breast cancer in Saudi females in eastern province of Saudi Arabia. Indian journal of medical sciences 1991, 45:85.

2. Albertson DG, Pinkel D: Genomic microarrays in human genetic disease and cancer. Human molecular genetics 2003, 12:145-152.

doi:10.1186/1471-2164-15-S2-P66

Cite this article as: Al-Harbi et al:: Array Comparative Genomic

hybridization of breast cancer in the kingdom of Saudi Arabia. BMC

Genomics 2014 15(Suppl 2):P66.

\section{Submit your next manuscript to BioMed Central} and take full advantage of:

- Convenient online submission

- Thorough peer review

- No space constraints or color figure charges

- Immediate publication on acceptance

- Inclusion in PubMed, CAS, Scopus and Google Scholar

- Research which is freely available for redistribution

Submit your manuscript at www.biomedcentral.com/submit
C Biomed Central 